\title{
ENVIRONMENTAL ENDOCRINE DISRUPTORS OF TESTICULAR FUNCTION
}

\author{
SAALU LC, OSINUBI AA* \\ Department of Anatomy, \\ Lagos State University College of Medicine, Ikeja, Lagos \\ *Corresponding Author \\ abrahamosinubi@yahoo.co.uk
}

\begin{abstract}
In the last 50 years the incidence of infertility, testicular and prostate cancers and associated maladies has increased significantly. Infertility now affects $15-20 \%$ of couples as opposed to $7-8 \%$ fifty years ago. Average sperm counts among adult men have decreased by $50 \%$ since 1938 , with a decline of $2 \%$ every year from 1973 . This decline in male reproductive health has been linked to an increased presence in the environment of chemical contaminants in the form of pesticides and plastics. Rapid and unplanned industrialization caused large amounts of these synthetic compounds and their by-products to be released in the environment (air, soil, water and food). Studies have shown that occupational exposure to pesticides caused neonatal deaths, congenital defects, testicular dysfunction and male infertility. Many of these chemicals found in our environment and households have oestrogenic properties ("xenoestrogens") and are toxic because they affect the endocrine system ("endocrine disruptors"). Evidence of the health hazards of endocrine disrupting chemicals continues to mount. In terms of male fertility, it now seems that these ubiquitous chemicals are a significant threat at various stages, from testicular development to sperm production to the functionality of healthy sperm. This class of chemicals appears to be threatening male fertility on several fronts. That endocrine disruptors abound in our environment is not in doubt. Clinicians and other health practitioners confronted with the challenges of managing male infertility should attempt to identify the aetiology of a possible exposure to endocrine disruptors, and initiate a plan to control and prevent exposure to others. In addition, concerted efforts should be made by both government and non-governmental agencies to institute local studies that will assess local endocrine disruptors, degree of contamination, level of exposure and proffer control and preventive measures. Emphasis should be placed on establishment of chemical screening and testing program, research into dose and vulnerable periods, institution of surveillance of disease incidence, improvement of exposure monitoring, and educating community leaders and the public in general.
\end{abstract}

Keywords: Endocrine disrupt ors, testis, testosterone, environment, infertility, peticides.

\section{INTRODUCTION}

Concern is fast growing that male sexual development and reproduction have changed for the worse over the past five decades (1). There seems to be some reasonable level of awareness among patients and health practitioners on testicular toxicants of therapeutic origin. For example, it has been demonstrated in animal studies that chloroquine, quinine, indomethacin, quinacrine are anti-spermatogenic (2-19). However, very little attention is given to testicular toxicants of environmental origin. A growing body of scientific research (20-24) indicates that substances in the environment may interfere with normal function of the endocrine system of humans and wildlife. These compounds may be synthetic (xenoestrogens) e.g., industrial chemicals, crop protection chemicals, or they may be natural like phytoestrogens. Some scientists have hypothesized that minute amounts of these chemicals are able to disrupt the endocrine system and cause cancer, harm male (e.g., reduced sperm counts) and other adverse effects (25). Therefore, those substances are called "endocrine disruptors."

\section{BACKGROUND}

The possibility that some chemicals may disrupt the endocrine systems in humans and animals has received considerable attention in the scientific and public community. Endocrine disruption is on the agenda of many experts' groups, steering committees and panels of governmental organizations, industry, and academia throughout the world. Because the disturbance of the endocrine system is a very sensitive topic, scientific findings or observations are often controversially discussed among scientists, environmentalists, and authorities.
Therefore, the aim of this review is to provide a science-based insight into endocrine disruption caused by chemicals. Owing to the complexity of this topic and the tremendous scientific research in this field, only a general overview can be given, which might be, however, beneficial and helpful for interested parties of academia and practicing endocrinologists.

Since the publication of Rachel Carson's silent spring (26), there has been concern that chemicals in the environment might exert profound and deleterious effects on wildlife populations, and that human health is inextricably linked to the health of the environment. The book is widely credited to have helped launch campaign against indiscriminate and uncontrolled use of pesticides and facilitated the ban of the pesticide dichlorodiphenyl-trichloroethane (DDT) $(27,28)$ in 1972 in the United States. The book documented detrimental effects of pesticides on the environment, particularly on birds. Carson argued that uncontrolled and unexamined use of pesticide was harming and even killing not only animals and birds, but also humans.

Although researchers have studied the endocrine effects of chemicals in the past, the term "endocrine disruptor" was coined in 1991 at a conference at Wingspread Conference Center in Racine, Wisconsin, United States of America. This conference was chaired by Theo Colborn, then with the World Wildlife Fund and the W. Alton Jones Foundation. The term was introduced into the scientific literature with her 1993 paper (29). In this paper, it was stated that environmental chemicals disrupt the development of the endocrine system, and that effects of exposure during development are invariably permanent.

The presence of these environmental chemicals disrupting the endocrine was thought to be the explanation for deteriorating reproductive health statistics globally (30-34). In the meta- 
analysis of 61 studies conducted worldwide between 1938 and 1990 (35), the following findings were reported: $15-20 \%$ couples were reported infertile as opposed to $7-8 \%$ couples 50 years before; the average sperm counts among male adults have decreased by $50 \%$; with a decline of $2 \%$ every year from 1973 (figure 1 ). This study supported a significant decline in sperm density in the United States and Europe, and that the changes could not be explained by methodological variation or selection bias but reflected a "true biological phenomenon".

\section{Figure 1: Sperm density declines: A meta-analysis}

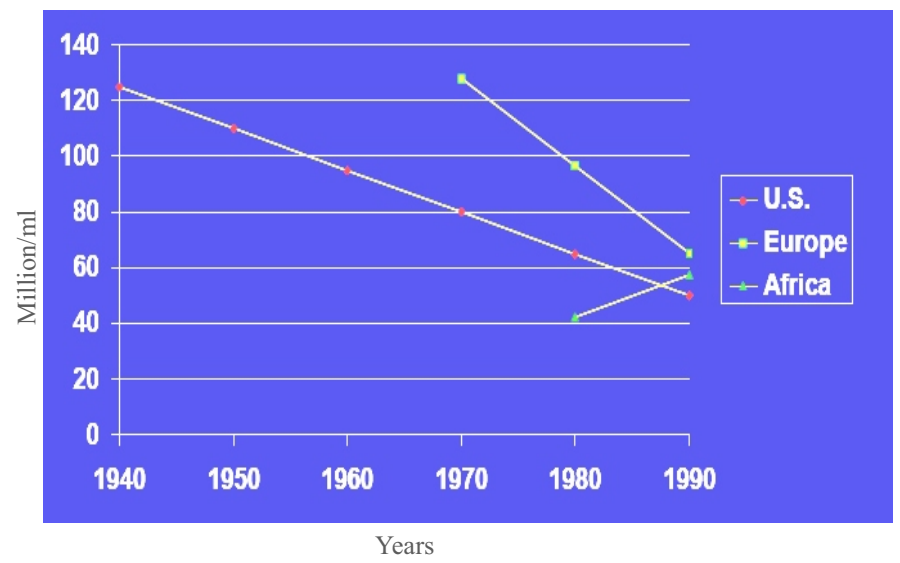

Source: Swan SH, Elkin EP, Fenster L. Environ Health Perspect, 1997.

\section{DEFINITIONS}

The working definition for endocrine disruptors that was adopted by the Organization for Economic Cooperative Development (OECD) at a workshop sponsored by the European Union (EU), World Health Organization (WHO), and OECD in Weybridge, United Kingdom in December 1996 is as follows: an endocrine disrupting chemical (EDC) is an exogenous substance that causes adverse health effects in an intact organism, or its progeny, secondary to changes in endocrine function (36). Endocrine disruptors (i) mimic natural hormones, (ii) inhibit the action of hormones, and/or (iii) alter the normal regulatory function of the endocrine systems (37). A potential EDC is a substance that possesses properties that might be expected to lead to endocrine disruption in an intact organism (36).

In May 1997, the U.S. Environmental Protection Agency (EPA) task force on endocrine disruption (EDSTAC) agreed on the following operational definition:

"An endocrine disruptor is an exogenous chemical substance or mixture that alters the function(s) of the endocrine system and thereby causes adverse effects to an organism, its progeny, or (sub) population" (38).

In a scientific statement by the endocrine society (39), an endocrine-disrupting substance is defined as a compound, either natural or synthetic, which through environmental or inappropriate developmental exposures alters the hormonal and homeostatic systems that enable the organism to communicate with and respond to its environment.

\section{PROPERTIES OF ENDOCRINE DISRUPTORS}

The properties of endocrine disruptors include the following $(40,41)$ :

They interfere with normal hormone function.

They are mostly fat soluble.

Most of them are synthetic.

Their effects are often significant at very low levels of exposure.
They are particularly effective during early development of the organism.

\section{THE REPRODUCTIVE ENDOCRINE SYSTEM}

The mammalian endocrine system is very dynamic, and undergoes frequent physiological fluctuations due to diurnal variations and cyclical hormonal feedback systems. Both hormonal modulations and chemical drug perturbations can affect the reproductivesystems in males and females $(42,43)$.

To allow a better understanding and appreciation of the mechanisms by which endocrine disruptors might exert their effects, a short introduction into the endocrine system of mammalian species shall be presented. Typically, the endocrine system is composed of several brain regions (such as the hypothalamus and pineal) and distinct glands (pituitary, thyroid, pancreas, adrenal, ovary, testis and placenta) that produce hormones that are either proteins or steroids. Hormones are chemical messengers produced by one tissue and conveyed by the bloodstream to another to effect physiological activity by transferring information and instructions between cells in animals and plants. They regulate growth and development, control the function of various tissues, support reproductive functions, regulate metabolism, and responses to surroundings, stress and injury. Indeed, hormones ensure appropriate communication, control and coordinate the body's functions.

The primary function of an endocrine system is to transform various exogenous stimuli into "chemical messengers" (hormones), resulting at least in the expression of the appropriate gene and thus in the synthesis of proteins or in the activation of already existing tissue-specific enzyme systems. The endocrine system represents an important tool for the timely coordination of development (e.g., induction of spawning cycles or sexual maturity) and metabolism (e.g., glucose homeostasis). Exogenous stimuli like day light, temperature and light as well as endogenous stimuli generally known as the "internal" clock are processed in the central nervous system. After a complex chain of biochemical processes, the hypothalamus secretes releasinghormones or inhibitory hormones that control the secretion of hormones from the pituitary gland. These secreted glycoproteins, the so-called glandotrophins, induce synthesis and release of tissue specific hormones in the various glands (thymus, thyroid, parathyroid, adrenals, pancreas, pineal, testes, and ovary). Hormones secreted by these internal glands travel through the bloodstream to their target tissues and target cells where they initiate a change in cellular activity by attaching to receptor proteins. This change is transmitted across the plasma membrane of a cell in different ways depending on the type of hormone. The cascade of different, interdependent physiological processes is regulated by complex mechanisms such as a negative-feedback pathway that is turned on and off in response to fluctuating levels of hormone. When hormone production of the gland peaks, the hormone acts as an inhibitor and causes the hypothalamus and/or pituitary gland to shut down or downregulate the pathway producing the substance. For example, in the male monkey, luteinizing hormone (LH) secretion is regulated by a negative feedback action of testicular testosterone that is exerted indirectly at the hypothalamic level to decelerate pulsatile gonadotrophin-releasing hormone release (44).

Although many steps of this sensitive system can be influenced by different external stimuli, most effects of endocrine disruptors observed and explained until now are attributed to the function of the gonads, which control the development of sexual differentiation, secondary sex characteristics, and functioning of sex organs (45). 


\section{MALE HORMONES}

The principal androgens are testosterone and dihydrotestosterone. They promote the development and differentiation of male reproductive organs before and after birth. Androgens determine secondary male sex characteristics, and also contribute to generalized anabolic functions of bone growth and increase protein synthesis, especially in muscles. Folliclestimulating hormone (FSH) and testosterone released from the Leydig cells under the influence of LH are the key regulators of the spermatogenic function of the testis. LH and FSH are produced in the anterior pituitary and are secreted episodically in response to the pulsatile release of gonadotrophin-releasing hormone from the hypothalamus. The principal role of $\mathrm{LH}$ in the regulation of spermatogenesis appears to be indirect in that it stimulates the release of testosterone from the interstitial cells of Leydig. Negative feedback from the concentration of testosterone in blood can down-regulate or block LH production. Androgens are transported in the blood mainly bound to a special testosteroneoestrogen-binding protein. Testosterone is metabolized both in peripheral tissues and in the liver. Degradation products such as androsterone and etiocholanolone, are excreted free or as glucuronide conjugates in the urine. Testosterone is reduced to the more potent androgen 5-á-dihydrotestosterone (DHT) by the microsomal fraction in target organs (e.g., prostate and epididymis) and is the precursor of oestradiol and oestrone. The male and female hormones (androgens and oestrogens, respectively) are actually secreted by both sexes. However, male hormones are secreted in higher quantities and are more potent in males whereas female hormones are secreted in higher quantities and are more active in females. Sex steroids have important functions during sexual differentiation of mammals, and this is genetically and hormonally regulated.

\section{MECHANISM OF ENDOCRINE DISRUPTION}

Endocrine disrupting chemicals can affect biological processes by several different modes of action. They may alter rate of synthesis or clearance of endogenous hormones. They may also act as agonists or antagonists of normal hormones. Owing to the complex nature of the endocrine system, it is obvious that external stimuli, e.g., exposure to xenobiotics (mimicking endocrine activity), can influence its important functions. The first observations of endocrine effects in wildlife research activities were focused on the explanation of main mechanisms underlying the observed effects. Several possible modes of actions have been cleared up in recent years:

\section{Direct interactions with hormone receptors \\ a) Agonistic action}

An exogenous agonist can be defined as a ligand that can bind to a receptor that finally leads to same effects that can be caused by endogenous hormone action. The potency of an exogenous agonist depends on its affinity to the receptor as well as on its ability to turn the receptor on. Well-known examples for oestrogen copycats are the synthetic oestrogen diethylstilbestrol (DES) and ethinyloestradiol. A large number of xenoestrogens, bind to the oestrogen receptor (ER) and evoke biological responses. The activity of a number of xenoestrogens is probably weak (compared to that of oestradiol). These substances (the xenoestrogens) interact with the binding pocket of the ER because they have chemical similarities to oestradiol (usually a phenolic A-ring). Reduced activity of xenoestrogens probably results from lack of fit of the remainder of the molecule within the binding pocket. However, at higher doses, these chemicals can evoke endocrine disruptive effects. The nature (oestrogenic or antioestrogenic) or magnitude of the response is a function of the substance itself, complexities within the various stages of the ER signaling pathway, as well as other factors (such as, plasma binding of xenoestrogens, cross-talk between ER and other signaling pathways, androgen antagonism, and alternate modes of oestrogen action)(46).

\section{b) Antagonistic action}

Some endocrine disruptors act on the hormone receptors via an antagonistic mechanism. An antagonist is a ligand that blocks or diminishes responses elicited by agonists because the receptor cannot be activated as usual. Competitive inhibition can lead to total de-activation of the receptor. Typical antagonists for hormone receptors are the herbicides vinclozolin, linuron and their metabolites $(47,48)$. Available toxicological evidence indicates that some environmental contaminants with strong affinity to the aryl hydrocarbon receptor (AhR) have antioestrogenic properties in both mammalian and non-mammalian in vivo and in vitro studies (49). Some endocrine disruptors interfere by attaching to protein receptors but then trigger an abnormal response in the cell. These triggers (as they are commonly called) cause growth at the wrong time, an alteration of metabolism or synthesis of a different product. The best known triggers are dioxin and dioxin-like chemicals. Dioxin acts through a hormone-like process to initiate entirely new responses. One study indicates that 2,3,7,8-tetrachlorodibenzop-dioxin (TCDD) directly acts with isolated cytosolic AhR under cell-freeconditions even without the presence of the nucleus and is capable of activating key protein kinases that are involved in the growth factorsignal-transduction pathway (50).

\section{Indirect interactions with the endocrine system}

a) Alteration in the hormone concentration can influence hormone metabolism in different ways. Hormone production can be impaired by inhibiting important enzyme-catalyzed reactions. Biosynthesis of oestrogen includes conversion of testosterone to an oestrogen catalyzed by the enzyme aromatase. Xenobiotics can inhibit this enzyme, leading to higher testosterone concentrations and to lower oestrogen concentrations. The effects observed can be interpreted as antioestrogenic or androgenic, depending on the point of view. This is probably the mechanism of action of tributyltin (TBT).

Hormone metabolism can also be influenced by induction of hormone-metabolizing enzymes like the cytochrome P-450 group in the liver. These enzymes have a key function in the synthesis and degradation of steroid hormones and their production or activity can be influenced by various xenobiotics such as dioxin (51).

An influence on the transport of the hormones via the blood stream to the target tissues and organs can also lead to a disturbance of the endocrine system. Chemicals that compete with sex steroids for the binding sites of transport proteins may increase the level of free and, therefore, effective hormones.

b) Alteration in hormone-receptor concentration can greatly alter hormone metabolism. In receptor-mediated processes, endogenous ligand and hormone receptor own a key function. Exogenous influence may, therefore, shift this sensitive balance. A so-called "down-regulation" of steroid hormones has been proposed for some antioestrogenic compounds, especially for dioxin. In this mode of action, the receptor is not directly involved in hormone metabolism, but its activation can have different influences on the endocrine system by (52):

An increased degradation rate of oestrogen receptors (down-regulation)

Induction of oestradiol metabolizing enzymes

Inhibition of gene expression controlled by oestradiol or 
growth promoters.

\section{SOME EFFECTS OF ENDOCRINE DISRUPTORS ON THE MALE REPRODUCTIVE AXIS}

Some endocrine disruptors alter the delicately balanced hypothalamo-pituitary-testicular axis, causing either a decline in pituitary-secreted gonadotrophins or an alteration in intratesticular concentrations of androgens (1). Endocrine disruptors (e.g., polychlorinated biphenyls [PCBs], DDT, dioxin, and some pesticides) are oestrogen-like and anti-androgenic chemicals in the environment. They mimic natural hormones, inhibit the action of hormones, or alter the normal regulatory function of the endocrine system and have potential hazardous effects on male reproductive axis causing infertility (37).

Antiandrogenic effects may take 2 forms: either a reduction in the amount of testosterone produced in the body or a replacement by the chemical in the cell's receptor where a testosterone molecule would normally go.

In addition, some oestrogen mimickers also have been observed to possess antiandrogenic effects. These new findings show that certain chemicals actually demasculinize, and can affect sperm counts and the structure of the prostate, or cause delayed puberty and extra nipples in males $(53,54)$.

Chemicals that act as androgen receptor (AR) agonists and antagonists or inhibit foetal steroidogenesis can induce reproductive malformations in humans and laboratory animals (53). Malformations and reduced fertility have been (53) seen even at levels ten-fold smaller than levels otherwise known to cause effects, suggesting that there is no "safe" threshold for exposure. The pesticides vinclozolin, procymidone, linuron and DDT are AR antagonists (54-58). Vinclozolin is a dicarboximide fungicide used in the control of Botrytis cinerea, Sclerotinia scierotiorum, and Moniliniam spp. on several fruits, vegetables, ornamental plants, and turf grass. Administration of vinclozolin to pregnant rats during the period of sexual differentiation (gestational day 14 to postnatal day 3) demasculinizes and feminizes the male offspring. Vinclozolin-treated male offspring display female-like anogenital distance (AGD) (distance from the anus to the genitals) at birth, retained nipples, cleft phallus with hypospadias, suprainguinal ectopic testes, a blind vaginal pouch, epididymal granulomas, and small to absent sex accessory glands $(54,58)$. In contrast, female offspring display no malformations or functional alterations.

Dieldrin has been shown to cause a decrease in sex ratio (number of males/number of males plus females) (59). It was found that exposure to the insecticide dieldrin causes a decrease in the production of male Daphnia (water flea), which may have long-term ecological effects. Chemicals that change Daphnia development or reproduction are definitely of ecological concern. Daphnia are ecologically important algae-consumers and fishfood in lakes all over the world. In particular, a decrease in the number of males has the potential of reducing Daphnia's ecological success over many generations, because the genetic recombination associated with sexual reproduction allows a population to adapt to on-going environmental change. In addition, the juvenile hormone-mimicking insecticides kinoprene, hydroprene, epofenonane, or fenoxycarb reduced reproductive rates in the water flea Daphnia magna (60).

Though a direct extrapolation of these effects observed in animals cannot be made to human, concerted efforts should, and must be made to commence evaluation of individuals suspected to have been exposed to these agents.

\section{SOME POTENTIAL ENDOCRINE DISRUPTORS IN THE ENVIRONMENT}

Chemical substances enter the environment in different ways. Pesticides are released at their point of application; industrial chemicals are unintentionally (our assumption) released by volatilization, leaking or leaching either during a product's lifetime or after ultimate disposal (table 1) (61). Natural hormones are excreted by various organisms and enter environmental compartments directly or through wastewater treatment plants (figures $2 \& 3$ ) (62). Once a substance has passed through the environment, it can undergo different fates, such as:

Further distribution between the environmental compartments water, air and

soil/sediment, as well as their sub-compartments.

Degradation and transfer processes in the compartments and sub-compartments.

As useful tools for predicting and understanding the behavior of chemicals in the environment, physicochemical properties can be used. The most important parameters are:

Water Solubility: The water solubility is the maximal concentration of a substance that can disolve in pure water at a given temperature.

Absorption coefficient: Absorption coefficient is a measure of the solubility of a substance in a liquid. The knowledge of absorption coefficient is useful for the description and prediction of the incorporation of a chemical substance or suspended matter in surface water.

Bioconcentration: Bioconcentration factor refers to the uptake from water and food.

\section{SOME EFFECTS OF ENDOCRINE DISRUPTORS ON WILDLIFE}

Environmental pollutants have been linked to adverse male reproductive effects in wildlife species ranging from invertebrates to mammals (63). Although such reproductive outcomes have been studied most intensively in amphibians and reptiles, related male reproductive disorders occur in many other species of wildlife. The causes of many of these disorders are unknown, but exposure to hormonally active agents in the environment has been implicated (1). Research on wildlife has shown that endocrine disrupting chemicals profoundly impair animal reproduction and development. All of the following examples represent animal populations that had extreme exposure to known endocrine disruptors:

Alligators in Lake Apopka, Florida, United States, contaminated with dicofol, DDT, other industrial chemicals showed reduced survival rates and egg hatching, combinations of male and reproductive organs, abnormal ovaries and testes, small penises, males with elevated oestrogen and females with elevated testosterone levels $(64,65)$. The Lake Apopka alligator is one of the bestknown wildlife species in which environmental xenoestrogens appear to have damaged the male reproductive system. The freshwater Lake Apopka in Florida is adjacent to the former Tower Chemical Company, which is now a superfund site. From 1970 to 1980, a mixture of pesticides containing high levels of DDT and its metabolites contaminated the area. Research comparing alligators from Lake Apopka to those in other Florida lakes found that Lake Apopka juvenile alligators have significantly smaller penis size as well as abnormalities in gonadal morphology and lower concentrations of plasma testosterone. Although the exact cause has not been determined, these alligators have significantly elevated serum concentrations of organochlorine pesticides 
compared to alligators at other lakes in Florida. Environmental xenoestrogens and antiandrogens such as these may contribute to abnormal or subnormal reproductive system development and appear to act on the males specifically during embryonic development (66).

Table 1: Endocrine Disruptors and their Sources

\section{CATEGORY}

Synthetic

(Pharmaceuticals):

Contraceptives

\section{Phytoestrogens (found in plants)}

Pesticides/herbicides (Currently in use)

\section{Organochlorines}

(Many now phased out)

\section{- Polychlorinated compounds} from industrial production or by products of banned substances.

- Organotins (found in antifoulants used to paint the fulls of ships)

- $\quad$ Phthalates (found in plasticizers)

G)Alkylphenols (surfactants, certain kinds of detergents used for removing oil)

\section{ENVIRONMENTAL ENDOCRINE DISRUPTORS}

Estrogens: Estradiol

Estrone, Estriol

Adrogens: Testosterone,

Androsterone

Ethinylestradiol, mestranol, Diethylstibestrol (DES)

Isoflavones (daidzen, genistein)Coumestan

Atrazine, Vinclozolin

DDT, Dieldrine

Polychlorinated dibenzodioxins

Municipal effluents

Agricultural runoff

Agricultural run-off Agricultural run-off Atmospheric transport Incineration

Land Fill

Tributyltin (TBT)

Harbours

Dibutyl phathalate, Bisphenol A (BPA)

Industrial effluents

Nonylphenol

Industrial and municipal effluent

DDT: Dichlorodiphenyl-trichloroethane

Source: Environment Canada “Endocrine Disrupting Substances Environment, 1999

Figure 2 : Potential exposure routes of natural human hormones

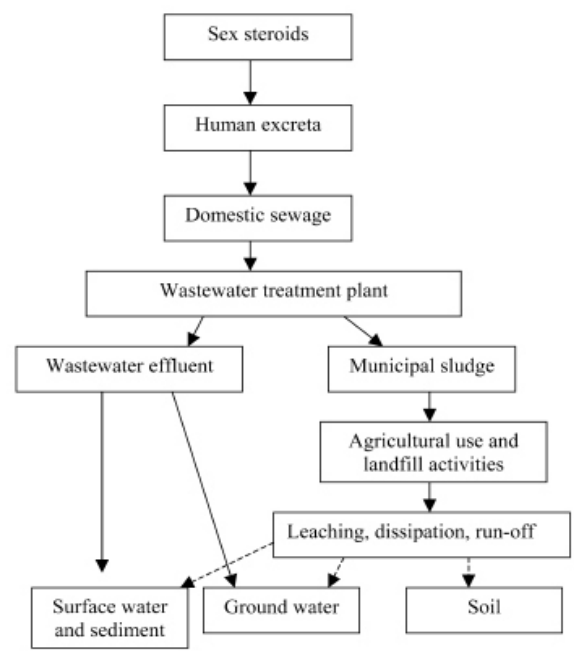

Source: International Union of Pure and Applied Chemistry (IUPAC). Pure and Applied Chemistry, 2003; 75: 631-681
Figure 3 : Potential exposure routes of sex steroids from livestock

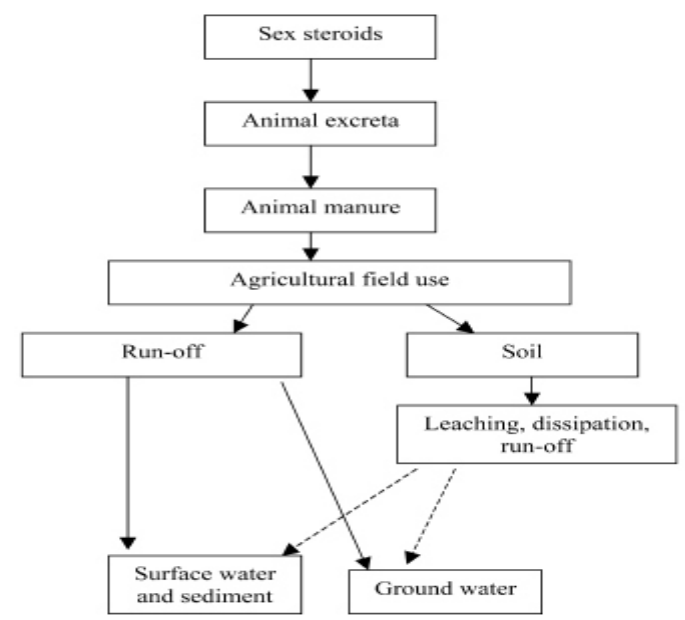

Source: International Union of Pure and Applied Chemistry (IUPAC). Pure and Applied Chemistry, 2003; 75: 631-681 
The Florida panther is another species in which environmental pollutants may be the cause of significant male reproductive defects (66). The endangered Florida panther suffers from inbreeding and vastly reduced habitat. The remaining population, estimated at only 30-50 individuals in 1995, exhibits a variety of problems, including reproductive and endocrine disorders (66). The males have an extremely high rate of cryptorchidism (estimated as $90 \%$ in 1995), as well as low ejaculate volume; low sperm concentration; poor sperm motility; and high proportion of sperm with morphologic abnormalities. Due to the small population size and the reduced habitat area, researchers have hypothesized that inbreeding may be the cause of the myriad health problems, but another possible explanation is exposure to environmental xenoestrogens. Florida panthers eat hogs, deer, armadillos and raccoons. Raccoons are suspected to account for much of the exposure to environmental xenoestrogens. In that area, raccoons eat fish and bioaccumulate mercury as well as endocrine-disrupting pesticides (67). Although the causes of the reproductive problems in the Florida panther have not been specifically identified, oestrogen mimics and antiandrogens in the environment are emerging as strong possibilities. These facts have significant implications for other wildlife species as well as for humans.

Studies of the population of western gulls nesting in the Channel Islands, off the coast of southern California and herring gulls from the Laurentian Great Lakes in the 1960s and 1970s, showed a high incidence of supernormal clutches and female-female pairing $(68,69)$. This is an abnormal phenomenon since gulls are long-lived monogamous species that usually lay 2 or 3 eggs every year. Fry and co-workers $(70,71)$ studying female-female pairing of western gulls, California gulls, and herring gulls concluded that the increased number of females and decreased population of the gulls could be a reflection of the fact that the majority of male gulls in 1970s were feminized and incapable of reproduction and also very few eggs in supernormal clutches were fertile. Embryonic feminization of males may result in suppression of sexual behaviour and self-exclusion from the breeding colonies $(72,73)$.

The feminizing effect of the pesticide DDT (dichlorodiphenyltrichloroethane) in roosters was reported in the 1950s (74).

Endocrine disruptors have been found to affect sexual development of salmon as well. Investigating the troubling phenomenon of sexual reversal/feminization in salmonids, Nagler et al., (75) found that $84 \%$ of phenotypic females tested positive for the male genetic marker and this could be attributable to exposure to endocrine disruptors.

Between 1996 and 2005 the carcasses of 355 harbour seals (Phoca vitulina) originating from the coast of SchleswigHolstein, Germany, were either found dead or were killed due to severe illness. Necropsy was performed in each case, in addition to histopathological, immunohistochemical, microbiological and parasitological examinations. The most common cause of death was bronchopneumonia caused by parasitic and/or bacterial infection of the lung, but in addition had high levels of PCBs and DDT in their tissues (76). Was the real culprit a compromised immune system caused by exposure to endocrine disrupting chemicals?

When taken together, these studies paint a picture that has a cumulative power that is not only compelling but urgent as well.

\section{SOME OTHER EXAMPLES OF TESTICULAR ENDOCRINE DISRUPTORS}

\section{Bisphenol A(BPA)}

BPA (2,2-Bis4-Hydroxyphenylpropane) is manufactured by the acid catalyzed condensation of phenol and acetone. It is one of the most important chemicals worldwide. BPA is a highproduction volume chemical used in the production of epoxy resins, polyester resins, polysulfone resins, polyacrylate resins, polycarbonate plastics, and flame retardants. Polycarbonate plastics are used in food and drink packaging; resins are used as lacquers to coat metal products such as food cans, bottle tops, and water supply pipes. Polycarbonate plastic, which is clear and nearly shatter-proof, is used to make a variety of common products including baby and water bottles, sports equipment, medical and dental devices, dental fillings and sealants, eyeglass lenses, CDs (compact discs) and DVDs (digital video discs), and household electronics (77). Exposure to the general population can occur through direct contact with BPA or by exposure to food or drink that has been in contact with a material containing BPA. BPA is a known oestrogenic compound; it reduces sperm production and causes increase in adult prostatic duct volume (78-83).

\section{Diethylstilbesterol (DES)}

DES is a synthetic steroid which was used for fattening of cattle as well as in humans to prevent miscarriages in the mid-20" century. This resulted in high exposure of the foetus to the synthetic sex steroid. The offspring of these women had to fight with some severe conditions: daughters developed vaginal cancer, sons suffered from malfunctions of the sexual organs such as sperm anomalies, hypospadias, and ectopic testes. These diseases were linked to perinatal exposure to DES during sensitive stages of sexual differentiation of the developing foetus (84-86). With data available both on women who took DES and on their adult children, the experience with this drug serves as a model demonstrating the possible effects on humans of exposure to synthetic oestrogens in utero. The DES experience showed that chemical exposure in utero can have serious, long-term, delayed effects; that substances that have little apparent effect in adults can cause substantial damage to a developing foetus; and that the human body can mistake a synthetic hormone for a natural one (87).

\section{Nonpersistent pesticides}

Nonpersistent pesticides (also referred to as "contemporary-use pesticides") are chemical mixtures that are currently available for application to control insects (insecticides), weeds (herbicides), fungi (fungicides) or other pests (e.g., rodenticides), as opposed to pesticides that have been banned from use in most countries (e.g., many of the formerly popular organochlorine pesticides such as DDT). Three common classes of nonpersistent pesticides in use today include organophosphates, carbamates and pyrethroids. Although environmentally nonpersistent, the extensive use of pest control in these various settings results in a majority of the general population being exposed to some of the more widely used pesticides at low levels. Exposure among the general population occurs primarily through the ingestion of foods that contain low levels of pesticide residue or through inhalation and/or dermal exposure in or around the home and in other indoor environments (39).

In Nigeria, rodenticides and insecticides are used indiscriminately and without any control. Rodenticides are even sold at the roadside on most of our highways. The present and 
long-term effects of these agents on mammals including humans are largely yet to be evaluated. Quite a number of these rodenticides and insecticides locally made are yet to be ascertained whether they are environmentally persistent or not; and this makes the case in our environment even more precarious.

A potential role of non-persistent pesticides (e.g., organophosphates, pyrethroids and carbamates) in the alteration of circulating oestradiol levels has been reported in experimental studies $(88,89)$. Although oestradiol is regarded as a female steroid hormone, it circulates in low but measurable levels in human males $(90,91)$ and has been reported to play an important role in male reproductive health (92-94). The net biologic effect of oestradiol in the testis appears to be inhibition of androgen production, either by limiting development and growth of the Leydig cell population or through direct action in the Leydig cell (95). However, oestradiol is now considered as a survival factor for germ cells $(99,100)$, and it appears that a balanced ratio between testosterone and oestradiol is critical to normal spermatogenesis (1). In a study (101) conducted on subjects attending a Massachusetts infertility clinic from years 2000-2003, it was reported that 3,5,6-trichloro-2-pyridinol, the major urinary metabolite of chlorpyrifos and chlorpyrifos-methyl, may be associated with altered oestradiol levels in adult men. The same study also found evidence suggestive of an inverse association between exposure to 1-naphthol, a urinary metabolite of carbaryl and naphthalene or its parent compound and circulating oestradiol.

Several studies have suggested an association between nonpersistent pesticide exposure and altered semen quality (101-110).

\section{THE ON-GOING DEBATE}

The hypothesis that chemicals in the environment can interfere with the development and action of hormones has sparked debate among scientists both because of the inconsistency of findings and because of certain features of the substances in question (111). Critics of the hypothesis argue that phytoestrogens and synthetic oestrogens are weaker than endogenous oestrogens; that exposure to oestrogenic substances occurring naturally in food outweighs exposure to environmental pollutants; and those chemicals that mimic oestrogen and those that block its action cancel each others' effects, much as acids and bases neutralize each other. These critics also discount evidence from animal studies, which are based on higher levels of exposure to contaminants than humans are likely to encounter in their environment, and challenge the relevance of wildlife studies conducted in "hyperpolluted" settings (112).

Those who advance the endocrine disruption hypothesis counter that while many exogenous hormones are less potent than those produced within the body; they are present in body tissues in much higher concentrations than are natural products. Furthermore, many synthetic endocrine disruptors may be stored in body tissue for long periods, the so called persistent organic pollutant (POP), whereas phytoestrogens are rapidly broken down or flushed out. Thus, the transfer of these substances to a developing foetus or a nursing infant is a function of the mother's lifetime exposure. In addition, some man-made chemicals that bind with a hormone receptor may not bind to proteins that limit the passage of endogenous hormones from the bloodstream into cells. Such chemicals (DES is known to be one) may therefore freely enter cells when natural hormones cannot (87).

Refuting the argument that the effects of oestrogenic and antioestrogenic compounds in the environment cancel each other out, supporters of the endocrine disruption hypothesis contend that these substances cannot interact in a way that is analogous to the interaction of an acid and a base. They add that studies suggesting otherwise have been based on homogenous cell cultures and therefore are not relevant to the complex, constantly changing biological system of a developing foetus (113).
Supporters of the hypothesis also note that as the dose of exposure to an endocrine disruptor increases, the magnitude of the effect may initially increase but then diminish. Thus, findings based on exposure to high doses of endocrine disruptors may not reflect effects of the same substances at lower doses. In addition, they point out, most studies have focused only on chemicals' oestrogenicity and have not examined other potential hormonal effects; for instance, while DDE has limited ability to bind with oestrogen receptors, it is a strong androgen antagonist (33).

Finally, those who hold to the endocrine disruption hypothesis agree that evidence from wildlife and laboratory animal studies does not prove their case in humans unequivocally. However, they state emphatically that humans and other vertebrates are similar enough so that even though specific effects may differ across species, wildlife can serve as "sentinels" of human risk, and wildlife studies can be used in conjunction with toxicological research to determine the effects of hormone disruptors on men's and women's reproductive health $(29,114)$.

\section{IMPLICATIONS AND CHALLENGES AHEAD}

The findings and uncertainties regarding endocrine disruption and reproductive health have suggested wide-ranging agenda for researchers and policy makers (115). The chief priority is to identify substances that may have deleterious effects, their mode of delivery and mechanism of action, the developmental stage at which they have their effects and the minimum concentration at which they pose risks. A broad range of outcomes needs to be investigated, including functional deficits in offspring and reproductive health traits other than the ability to conceive and procreate. Changes in these outcomes over time and at various levels of exposure must also be assessed.

Other areas of high priorities include: defining normal variability in reproductive health characteristics so that trends can be identified reliably and hypotheses about their causes ascertained; determining the way endocrine disruptors interact; and developing risk assessment methods that take these interactions into account. This information could be used as a basis for considering regulatory measures aimed at limiting exposures to substances with known or suspected effects.

\section{THE HOLISTIC APPROACH}

Testicular function and indeed the reproductive health are exquisitely sensitive to an individual's total environmentincluding physical, biological and social factors. The relative effect of these features may vary in different parts of the world or even within a country.

In our environment a review of environmental endocrine disruptors (and potential endocrine disruptors) would necessary include "non-chemical endocrine disruptors" belonging to the social environment. Worthy of specific mention is stress which could disrupt the testicular endocrine function through the hypothalamo-pitutary-gonadal axis, hypothalamo-pitutarythyroid-gonadal axis, and the hypothalamo-pitutary-adrenal/ gonadal axis.

\section{CONCLUSIONS}

In view of the prevailing scientific debate on environmental endocrine disruptor hypothesis, a decision could be made to wait until sufficient data accumulate to show cause and effect before taking action or to apply a precautionary principle. The latter will involve avoiding practices which have potential to cause damage even when all facts are not yet known. We should seek a delicate 
balance between the two extreme scientific opinions. There is need for ecological "common sense". For instance, if the fish in the rivers used for drinking water display sex reversal, action should be taken immediately. If minor or localized disturbances are seen in wild life ecology, the best course of action would be long-term data collection.

It should also be noted that although surface and ground water have been extensively surveyed in several geographical areas, there is paucity of data from Africa. This situation merits additional comments because whereas the industries and their finished products are domiciled in the developed world, evidence abound that their toxic wastes are dumped in the developing world. According to a time-tested toxicology rule, "dose makes poison". This continent may therefore be gradually getting "poisoned". Concerted efforts should also be made by clinicians to attempt to identify aetiology of a possible exposure to endocrine disruptors when investigating cases of male infertility. Finally, the government at all levels must invest in relevant capacity building, training and re-training of environmental toxicologists.

\section{REFERENCES}

1. Osinubi AA. Quinine-induced cytoarchitectural and morphometric alterations in the testes of Sprague-Dawley rats (Ph.D. Thesis). Lagos: University of Lagos, 2006, pp. 1225.

2. Chow PY, Holland MK, Suter DA, White IG. Evaluation of ten potential organic spermicides. Int J Fertil, 1980; 25: 281286.

3. Trifunac NP, Berstein GS. Inhibition of the metabolism and motility of human spermatozoa by various alkaloids. Contraception, 1982; 25: 69-87.

4. Pearson RM, Hong CY, Patel LG, Turner P, Potts DM, Wheeler R, Zipper J. Studies on membrane-active vaginal spermicides. Contracept Deliv Syst, 1984; 5: 303-309.

5. Okanlawon, AO, Noronha CC, Ashiru OA. An investigation into the effects of chloroquine on fertility of male rats. West Afr JMed, 1993; 12: 118-121.

6. Okanlawon AO, Ashiru OA. Morphological changes in rat seminiferous tubules produced by chloroquine. Niger Postgrad Med J, 1996; 3: 105-109.

7. Oremosu AA, Ashiru OA. The effect of chloroquine and testosterone on Sperm motility. Nig Qt J Hosp Med, 1996; 6: 238-241.

8. Okanlawon AO, Ashiru OA. Sterological estimation of seminiferous tubular dysfunction in chloroquine treated rats. Afr JMed Med Sci, 1998; 27: 101-106.

9. Okanlawon A, Kusemiju O, Dym M. Direct toxic effects of clinical doses of chloroquine on transferring secretion in immature rat Sertoli cells in vitro. Niger

Med J, 2001: 8: 165-169.

10. Osinubi AA, Akinlua JT, Agbaje MA, Noronha CC, Okanlawon AO. Effects of short-term administration of quinine on the seminiferous tubules of Sprague-Dawley rats. Nig J Health Biomed Sci, 2004; 3(1): 1-7.

11. Osinubi AA, Noronha CC, Okanlawon AO. Reversal of quinine-induced testicular toxicity by testosterone in rat. Nig QtJHosp, 2004; 14(2): 121-125.

12. Osinubi AA, Noronha CC, Okanlawon AO. Effects of quinine and ascorbic acid on testicular malondialdehyde and sperm quality in the rat. JClin Sci, 2004;4:1-6.

13. Osinubi AA, Noronha CC, Okanlawon AO. Morphometric and stereological assessment of the effects of long-term administration of quinine on the morphology of rat testis. West Afr JMed, 2005; 24(3): 200-205.

14. Osinubi AA, Noronha CC, Okanlawon AO. Attenuation of quinine-induced testicular toxicity by Ascorbic acid in rat: A stereological approach. Afr J Med Med Sci, 2005; 34: 213 219.

15. Osinubi AA, Noronha CC, Okanlawon AO. Cytoarchitectural and morphometric changes in the testis induced by quinine administration in rabbits. West Afr $J$ Anat, 2005; 8: 73-80.

16. Osinubi AA, Noronha CC, Akosile SK, Okanlawon AO. Histomorphometric and seminal analyses: Testosterone prevents quinine-induced testicular toxicity in SragueDawley rats. West Afr J Anat, 2005; 8: 109-116.

17. Akpan HB, Noronha CC, Osinubi AA, Orakwue CO, Kusemiju TO, Okanlawon AO. Effects of indomethacin on the seminiferous tubules of male Sprague-Dawley rats: A stereological study. West Afr J Anat, 2005; 8: 151-159.

18. Osinubi AA, Ajala MO, Noronha CC, Okanlawon AO. Quinine lowers serum and testicular testosterone in adult Sprague-Dawley rats. Afr JMed Med Sc, 2006; 35: 425-430.

19. Osinubi AA, Daramola AO, Noronha CC, Okanlawon AO, Ashiru OA. The effect of quinine and ascorbic acid on rat testicles. West Afr JMed, 2007; 26(3): 217-221.

20. Colborn T, Clement C. Advances in modern environmental toxicology. Vol. XXI. Chemically-induced alterations in sexual and functional development: The Wildlife/Human connection. New Jersey: Princeton Scientific Publishing Co., Inc., 1992.

21. Gray LE, Jr. Tiered screening and testing strategy for xenoestrogens and antiandrogens. Toxicol Lett, 1998; 28; 102-103; 677-680.

22. Gray LE, Jr. Xenoendocrine disrupters: laboratory studies on male reproductive effects. Toxicol Lett, 1998; 28: 102$103 ; 331-335$.

23. Gray LE, Jr, Ostby J, Monosson E, Kelce WR. Environmental antiandrogens: low doses of the fungicide vinclozolin alter sexual differentiation of the male rat. $J$ Toxicol Ind Health, 1992; 15: 48-64.

24. Gray LE, Jr, Ostby J, Cooper RL, Kelce WR. The estrogenic and antiandrogenic pesticide methoxychlor alters the reproductive tract and behavior without affecting pituitary size or LH and prolactin secretion in male rats. J Toxicol Ind Health, 1999; 15: 37-47.

25. Sharpe RM, Skakkebaek NE. Are oestrogens involved in falling sperm counts and disorders of the male reproductive tract? Lancet, 1993; 341: 1392-1395.

26. Carson R. Silent Spring. Boston: Houghton Mifflin, 1962.

27. Environmental Protection Agency (EPA) reference: DDT. Retrieved 2007-11-04.

28. Lear L. Rachel Carson: Witness for Nature. New York: Henry Hoyten, 1997.

29. Colborn T, Saal FS, Soto AM. Developmental effects of endocrine-disrupting chemicals in Wildlife and Humans. Environ Health Perspect, 1993; 101:378-384.

30. Working PK. Male reproductive toxicology: comparison of the human to animal models. Environ Health Prospect, 1988; 77: 37-44.

31. Carlsen E, Giwercman A, Keiding N, Skakkebaek NE. Evidence for decreasing quality of semen during past 50 years. $B M J, 1992 ; 12 ; 305(6854)$ : 609-613.

32. Michal F, More S, Ase P. Impact of the environment on Reproductive Health: Executive summary. Environ Health Prospect, 1993; 101(Supp 2): 159-167.

33. Kelce WR, Monosson E, Gamcsik MP, Laws SC, Gray LE Jr. Environmental hormone disruptors: evidence that vinclozolin developmental toxicity is mediated by antiandrogenic metabolites. Toxicol Appl Pharm, 1994; 126: $276-285$. 
34. Auger J, Kunstmann JM, Czyglik F, Jouannet P. Decline in semen quality among fertile men in Paris during the past 20 years. NEnglJMed, 1995; 332(5): 327-328.

35. Swan SH, Elkin EP, Fenster L. Have sperm densities declined? A reanalysis of global trend data. Environ Health Perspect, 1997; 105(11): 1228-1232.

36. European Workshop on the Impact of Endocrine Disruptors on Human Health and Wildlife. Report of Proceedings, 2-4 December, Weybridge, UK, 1996.

37. Sikka SC, Wang R. Endocrine disruptors and estrogenic effects on male reproductive axis. Asian J Androl, 2008; 10: 134-145.

38. U.S. Government Environmental Protection Agency (EPA). Endocrine Disruptor Screening Testing Advisory Committee (EDSTAC), final report, 1998.

39. The Endocrine Society. Endocrine-Disrupting Chemicals. An Endocrine Society Scientific Statement. 2009.

40. Price TM, Murphy SK, Youngai VY. Perspectives: The possible influence of assisted reproductive technologies on transgenerational reproductive effects of environmental endocrine disruptors. Toxicol Sci, 2007; 96: 218-226.

41. Noble D. Prologue: Mind over molecule: Activating biological demons. Ann NY Acad Sci, 2008; 1123: 11-19.

42. Thomas JA. Drugs and chemicals that affect the endocrine system. Int J Toxicol, 1998; 17(2): 129-138.

43. Savitz DA, Arbuckle T, Kaczor D, Curtis KM. Male pesticide exposure and pregnancy outcome. Am J Epidemiol, 1997; 145(12): 1025-1036.

44. Shibata M, Friedman RL, Ramaswamy S, Plant TM. Evidence that down regulation of hypothalamic KiSS-1 expression is involved in the negative feedback action of testosterone to regulate luteinising hormone secretion in the adult male Rhesus Monkey (Macaca mulatta). J Neuroendocrinol, 2007, 19(6): 432-438.

45. Eubanks MW. Hormones and Health. Environ Health Perspect, 1997; 105: 482-486.

46. Witorsch RJ. Endocrine Disruptors: Can Biological Effects and Environmental Risks Be Predicted? Regul Toxicol Pharmacol, 2002; 36(1): 118-130.

47. Kelce WR, Stone CR, Laws SC, Gray LG, Kemppainen JA, Wilson EM. Persistent DDT Metabolite p,p'-DDE is a Potent Androgen Receptor Antagonist. Nature, 1995; 373: 581-585.

48. Mathur P. Impact of environmental toxicants on testicular function. Immunol Endo and Met Agents in Med Chem, 2008; 1:79-90.

49. Mortensen AS, Arukwe A. Activation of estrogen receptor signaling by the dioxin-like aryl hydrocarbon receptor agonist, 3,32 ,4,42 ,5-Pentachlorobiphenyl (PCB126) in salmon in vitro system. Toxicol Appl Pharmacol, 2008; 227(2): 313-324.

50. Matsumura F. Mechanism of action of dioxin-type chemicals, pesticides, and other xenobiotics affecting nutritional indexes. Am JClin Nutr, 1995; 61: 695S-701S.

51. Safe S, Wang F, Porter W, Duan R, McDougal A. Ah receptor agonists as endocrine disruptors: Antiestrogenic activity and mechanisms. Toxicol Lett, 1998; 102-103: 343-347.

52. vom Saal FS, Cooke PS, Buchanan DL, Palanza P, Thayer KA, Nagel SC, Parmigiani S, Welshons WV. A physiologically based approach to the study of bisphenol A and other estrogenic chemicals on the size of reproductive organs, daily sperm production, and behavior. Toxicol Ind Health, 1998; 14, 239-260.

53. Gray LE, Jr, Ostby J, Furr J, Wolf CJ, Lambright C, Parks L, Veeramachaneni DN, Wilson V, Price M, Hotchkiss A, Orlando E, Guillette L. Effects of environmental antiandrogens on reproductive development in experimental animals. Hum Reprod Update, 2001; 7(3): 248-264.

54. Kelce WR, Monosson E, Gamcsik MP, Laws SC, Gray LE Jr. Environmental hormone disruptors: evidence that vinclozolin developmental toxicity is mediated by antiandrogenic metabolites. Toxicol Appl Pharmacol, 1994; 126(2): 276-285.

55. Ostby J, Kelce WR, Lambright C, Wolf CJ, Mann P, Gray LE Jr. The fungicide procymidone alters sexual differentiation in the male rat by acting as an androgenreceptor antagonist in vivo and in vitro. Toxicol Ind Health, 1999; 15(1-2): 80-93.

56. Lambright C, Ostby J, Bobseine K, Wilson V, Hotchkiss AK, Mann PC, Gray LE Jr. Cellular and molecular mechanisms of action of linuron: an antiandrogenic herbicide that produces reproductive malformations in male rats. Toxicol Sci, 2000; 56(2): 389-399.

57. McIntyre BS, Barlow NJ, Wallace DG, Maness SC, Gaido $\mathrm{KW}$, Foster PM. Effects of in utero exposure to linuron on androgen-dependent reproductive development in the male Crl:CD(SD)BR rat. Toxicol Appl Pharmacol, 2000; 167(2): 87-99.

58. Wolf CJ, LeBlanc GA, Gray LE Jr. Interactive Effects of Vinclozolin and Testosterone Propionate on Pregnancy and Sexual Differentiation of the Male and Female SD Rat. Toxicol Sci, 2004; 78: 135-143.

59. Dodson SI, Merritt CM, Torrentera L, Winter KM, Tornehl CK, Girvin K. Dieldrin reduces male production and sex ratio in Daphnia galeata mendotae. Toxicol Ind Health, 1999; 15(1-2): 192-199.

60. Oda S, Tatarazako N, Watanabe H, Morita M, Iguchi T. Production of male neonates in Daphnia magna (Cladocera, Crustacea) exposed to juvenile hormones and their analogs. Chemosphere, 2005; 61(8): 1168-1174.

61. Environment Canada. Endocrine disrupting substances in environment. 1999.

62. International Union of Pure and Applied Chemistry (IUPAC). Pure Appl Chem, 2003; 75: 631-681.

63. Harrison PT, Holmes P, Humfrey CD. Reproductive health in humans and wildlife: are adverse trends associated with environmental chemical exposure? Sci Total Environ, 1997; 205:97-106.

64. Guillete LJ. In: Popkin DR, Peddle LJ., editors, Women's Health Today: Perspectives on Current Research and Clinical Practice. New York: Parthenon, 1994, pp. 96-110.

65. Mines MR, Bryan TA, Katsu Y, Kohno B, Moore C, Iguchi $\mathrm{T}$, et al. Increased Post hatching Mortality and Loss of Sexually Dimorphic Gene Expression in Alligators (Alligator mississippiensis) from a Contaminated Environment. Biol Reprod, 2008; 78: 932-938.

66. Facemire CF, Gross TS, Guillette LJ. Jr. (1995). Reproductive impairment in the Florida panther: nature or nurture? Environ Health Perspect, 1995: 103(suppl 4): 79-86.

67. Campbell PM, Hutchinson TH. Wildlife and endocrine disruptors: requirements for hazard identification. Environ Toxicol Chem, 1998; 17: 127-135.

68. Hunt GL, Hunt MW. Female-female pairing in Western Gulls (Larus occidentalis) in southern California. Science, 1977: 196: 1466-1476.

69. Shugart GW. Frequency and distribution of polygyny in Great Lakes herring gulls in 1978. Condor, 1980; 82: 426429.

70. Fry DM, Toone CK. DDT-induced feminization of gull embryos. Science, 1981;213: 922-924.

71. Fry DM, Toone CK, Speich SM, Peard RJ. Sex ratio skew and breeding patterns of gulls: Demographic and 
toxicological considerations. Standard Avian Biology, 1987; 10:26-43.

72. Wingfield JC, Newman AL, Hunt GL, Farner DS. Endocrine aspects of female-female pairing in the Western Gulls (Larus occidentails wymani). Animal Behaviour, 1982;30:9-22.

73. Hunt GL, Newman AL, Warner MH, Wingfield JC, Kaiwi J. Comparative behavior of male-female and female-female pairs among Western Gulls prior to egg laying. Condor, 1984; 86: $157-162$.

74. Burlington H, Lindeman VF. Effect of DDT on testes and secondary sex characters of white leghorn cockerels. Proc Soc Exp Biol Med, 1950; 74: 48-51.

75. Nagler JJ, Bouma J, Thorgaard GH, Dauble DD.2001. High Incidence of a Male-Specific Genetic Marker in Phenotypic Female Chinook Salmon from the Columbia River, Environ Health Perspect, 2001; 109: 67-69.

76. Siebert U, Wohlsein $P$, Lehnert K, Baumgärtner W. Pathological Findings in Harbour Seals (Phoca vitulina): 1996-2005. JComp Pathol; 2007; 137(1): 47-58.

77. National Toxicology Program U.S. Department of Health and Human Services NTP-CERHR Expert Panel Report on the Reproductive and Developmental Toxicity of Bisphenol A, 2007.

78. European-Union. Risk Assessment Report - 4,4'isopropylidenediphenol (Bisphenol A), 2003.

79. Staples CA, Dorn PB, Klecka GM, O'Block ST, Harris LR. A review of the environmental fate, effects, and exposures of bisphenol A. Chemosphere, 1998; 36:2149-2173.

80. Anway MD, Skinner MK. Epigenetic transgenerational actions of endocrine disruptors. Endocrinology, 2006; $147(6$ Suppl): S43-S49.

81. Delbès G, Levacher C, Habert R. Estrogen effects on fetal and neonatal testicular development. Reproduction, 2006, 132(4): 527-538.

82. Ho S, Tang W, Belmonte de Frausto J, Prins GS. Developmental Exposure to Estradiol and Bisphenol A Increases Susceptibility to Prostate Carcinogenesis and Epigenetically Regulates Phosphodiesterase Type 4 Variant 4. Cancer Res, 2006; 66, 5624-5632.

83. Polsky JY, Aronson KJ, Heaton JPW, Adams MA. Pesticides and Polychlorinated Biphenyls as Potential Risk Factors for Erectile Dysfunction. JAndrol, 2007; 28(1): 28-37.

84. Gill WB, Schumacher GFB, Bibbo M, Straus FH, and Schoenberg HW. 1979. Association of diethylstilbestrol exposure in utero with cryptorchidism, testicular hypoplasia, and semen abnormalities. JUrol, 122:36-39.

85. Giusti RM, Iwamoto K, Hatch EE. Diethylstilbestrol revisited: a review of the long-term health effects. Ann Intern Med, 1995; 122(10): 778-788.

86. Newbold RR, Padilla-Banks E, Jefferson WN. Adverse effects of the model environmental estrogen diethylstibestrol are transmitted to subsequent generations. Endocrinology, 2000; 147: 11-17.

87. Colborn T, Dumanoski D, Myers JP. Our Stolen Future: Are We Threatening Our Fertility, Intelligence, and Survival? - A Scientific Detective Story. New York: Penguin Books Ltd., 1996, pp. 66-67.

88. Usmani KA, Cho TM, Rose RL, Hodgson E. Inhibition of the human liver microsomal and human cytochrome P450 1A2 and 3A4 metabolism of estradiol by deployment-related and other chemicals. Drug Metab Dispos, 2006; 34: 1606-1614.

89. Jeong SH, Kim BY, Kang HG, Ku HO, Cho JH. Effect of chlorpyrifos-methyl on steroid and thyroid hormones in rat F0- and F1-generations. Toxicology, 2006; 220: 189-202.

90. Tivesten A, Hulthe J, Wallenfeldt K, Wikstrand J, Ohlsson C, Fagerberg B. Circulating estradiol is an independent predictor of progression of carotid artery intima-media thickness in middle-aged men. J Clin Endocrinol Metab, 2006; 9: 44334437.

91. Pentikainen V, Erkkila K, Suomalainen L, Parvinen M, Dunkel L. Estradiol acts as a germ cell survival factor in the human testis in vitro. J Clin Endocrinol Metab, 2000; 85: 2057-2067.

92. Eddy EM, Washburn TF, Bunch DO, Goulding EH, Gladen BC, Lubahn DB, Korach KS. Targeted disruption of the estrogen receptor gene in male mice causes alteration of spermatogenesis and infertility. Endocrinology, 1996; 137: 4796-4805.

93. Hess RA, Bunick D, Lee KH, Bahr J, Taylor JA, Korach KS, Lubahn DB. A role for oestrogens in the male reproductive system. Nature, 1997; 390: 509-512.

94. Robertson KM, O’Donnell L, Jones ME, Meachem SJ, Boon WC, Fisher CR, Graves KH, McLachlan RI, Simpson ER. Impairment of spermatogenesis in mice lacking a functional aromatase (cyp 19) gene. Proc Natl Acad Sci USA, 1999; 96: 7986-7991.

95. Abney $\mathrm{T}$. The potential roles of estrogens in regulating Leydig cell development and function: A review. Steroids, 1999; 64: 610-617.

96. Shetty G, Krishnamurthy H, Krishnamurthy HN, Bhatnagar S, Moudgal RN. Effect of estrogen deprivation on the male reproductive physiology of male and female primates. $J$ Steroid Biochem Molec Biol, 1997; 61: 26-30.

97. Pelliniemi LJ, Fröjdman K, Paranko J. Embryological and prenatal development and function of Sertoli cells. In: Russell LD, Griswold MD, editors, The Sertoli cell. Clearwater: Cache River Press, 1993, pp. 88-113.

98. Meeker JD, Ravi SR, Barr DB, Hauser R. Circulating estradiol in men is inversely related to urinary metabolites of nonpersistent insecticides. Reprod Toxicol, 2008; 25(2): 184-191.

99. Whorton MD, Milby TH, Stubbs HA, Avashia BH, Hull EQ 1979 Testicular function among carbaryl-exposed exployees. J Toxicol Environ Health, 1979; 5: 929-941.

100. Wyrobek AJ, Watchmaker G, Gordon L, Wong K, Moore D, Whorton D. 1981 Sperm shape abnormalities in carbarylexposed employees. Environ Health Perspect, 1981; 40: 255-265.

101.Larsen SB, Giwercman A, Spano“ M, Bonde JP. A longitudinal study of semen quality in pesticide spraying Danish farmers. The ASCLEPIOS Study Group. Reprod Toxicol, 1998; 12:581-589.

102.Juhler RK, Larsen SB, Meyer O, Jensen ND, Spano“ M, Giwercman A, Bonde JP. Human semen quality in relation to dietary pesticide exposure and organic diet. Arch Environ Contam Toxicol, 1999; 37: 415-423.

103. Abell A, Ernst E, Bonde JP. Semen quality and sexual hormones in greenhouse workers. Scand $J$ Work Environ Health, 2000; 26: 492-500.

104.Padungtod C, Savitz DA, Overstreet JW, Christiani DC, Ryan LM, Xu X. Occupational pesticide exposure and semen quality among Chinese workers. J Occup Environ Med, 2000; 42: 982-992.

105. Oliva A, Spira A, Multigner L. Contribution of environmental factors to the risk of male infertility. Hum Reprod, 2001; 16: 1768-1776.

106. Swan SH, Kruse RL, Liu F, Barr DB, Drobnis EZ, Redmon JB, Wang C, Brazil C, Overstreet JW. Semen quality in relation to biomarkers of pesticide exposure. Environ Health Perspect, 2003; 111: 1478-1484.

107.Kamijima M, Hibi H, Gotoh M, Taki K, Saito I, Wang H, Itohara S, Yamada T, Ichihara G, Shibata E, Nakajima T, 
Takeuchi Y. A survey of semen indices in insecticide sprayers. JOccup Health, 2004; 46: 109-118.

108. Meeker JD, Ryan L, Barr DB, Herrick RF, Bennett DH, Bravo R, Hauser R. The relationship of urinary metabolites of carbaryl/naphthalene and chlorpyrifos with human semen quality. Environ Health Perspect, 2004; 112: 1665-1670.

109. Tan LF, Sun XZ, Li YN, Ji JM, Wang QL, Chen LS, Bian Q, Wang SL. Effects of carbaryl production exposure on the sperm and semen quality of occupational male workers. Zhonghua Lao Dong Wei Sheng Zhi Ye Bing Za Zhi, 2005; 23 : 87-90.

110. Lifeng T, Shoulin W, Junmin J, Xuezhao S, Yannan L, Qianli W, Longsheng C. Effects of fenvalerate exposure on semen quality among occupational workers. Contraception, 2006; 73: 92-96.

111. Stone, R. Environmental estrogen stir debate. Science, 1994; 265-310.
112. Safe SH. Environmental and Dietary Estrogens and Human Health: Is There a Problem? Environ Health Perspect, 1994; 103: 346-351.

113. vom Saal FS. Environmental Estrogenic Chemicals: Their Impact on Embryonic Development. Human and Ecological Risk Assessment, 1995; 1(2): 3-15.

114. Vaithinathan S, Saradha B, Mathur P. The hostile role of environmental toxicants. Recent advances and challenges in reproductive health research. New Delhi: Indian Council of Medical Research, 2008; 379-391.

115. Marcus M, Silbergeld E, Mattison D. A reproductive hazards research agenda for the 1990s. Research Needs Working Group. Environ Health Perspect, 1993; 101(Suppl 2): $175-180$.

References and further reading may be available for this article. To view references and further reading you must purchase this article. 